\title{
Assessment of Drudgery Reduction of Different Weeders in Paddy for Farm Women
}

\author{
C. Tamilselvi ${ }^{1}$, R. Manimekalai ${ }^{2}$, P. Yogameenakshi $^{2}$ \\ V.A. Vijayashanthi ${ }^{2}$ and M. Sathish ${ }^{3}$ \\ ${ }^{1}$ Agricultural College and Research Institute, Eachangkottai, Thanjavur, India \\ ${ }^{2}$ Krishi Vigyan Kendra, Tirur, Tiruvallur dist., India \\ ${ }^{3}$ Regional Research Station, Virudhachalam, Cuddalore dist, India \\ *Corresponding author
}

\section{A B S T R A C T}

\begin{tabular}{l} 
K e y w o r d s \\
Drudgery, \\
Economics, Posture, \\
Paddy, Conoweeder \\
\hline Article Info \\
\hline $\begin{array}{l}\text { Accepted: } \\
\text { 07 September } 2020 \\
\text { Available Online: } \\
\text { 10 October } 2020\end{array}$ \\
\hline
\end{tabular}

\begin{abstract}
Weed control is a major issue in Paddy cultivation for farmers / farm owners. Most farm women control weeds using hand hoe tools. Nonetheless, this approach proves useful but requires hard-hitting work and is full of sullenness. Bending for a prolonged period of time increases their physical load and they also suffer many types of muscular problems and because of these women's efficiency decreases dramatically. Non availability of labour during peak season is added burden to the farmers. Modified conoweeder was evaluated for its performance with existing conoweeder in farmer's field at Krishi Vigyan Kendra, Tirur, Tiruvallur district. This experiment was carried out in 20 farmers field of Tiruvallur district during the year 2017-18for assessing the reduction in drudgery in weeding operation by different weeders in paddy. The experiment consisted of 20 women farmers belonging to age group of 25- 40 years who were working regularly in the field. The experiment for hand weeding method consisted of 12 women farmers belonging to the age group of $20-48$ years. The weeding efficiency for modified conoweeder was on par (88\%) with the weeding efficiency of manual weeding $(89 \%)$, while the weeding efficiency of conoweeder was comparatively low (79\%).The cost of operation of different weeders revealed that, manual weeding was costliest among all the methods. The cost of operation for modified conoweeder was Rs. 2800/ha and for conoweeder was Rs. 3200/ha. The pulse rate was recorded higher in conoweeder (116) compared to modified weeder (108) and manual weeding (106).
\end{abstract}

\section{Introduction}

A large percentage of rural women participate in agriculture and allied sectors. The migration of rural males to urban areas compels women to do their house hold chores as well as the agricultural work that men have done in the past. Women make up $70 \%$ of the major agricultural work, including sowing, planting, weeding, threshing, cleaning, winnowing, grading, and $60 \%$ of the agricultural population (NSWF, 2014). As a 
result, women increase their workload, which can cause significant physical, mental fatigue and other health problems (Agarwal, 2007).Modernization of agriculture is taking place at a national level, but women continue to pursue addictive agriculture, while mechanical activities are carried out by men (Singh, 2002). To get the full benefit of mechanization, it is important to use appropriate tools for weeding, which will reduce the cost of weeding operation and cultivation. Weeding is one of the most important cultural activities in the crop production system and it is carried out by women by using hand hoe. (Prakash et al., 2014).Although this method of weeding proves to be beneficial as it controls $98 \%$ of weed, it requires more labor and it involves more drudgery especially to the women farmers. During hand weeding, they adopt the bending and sitting posture of the body, which increases their physical workload and, in addition, they suffer from a variety of muscle-skeletal problems, resulting in a greater capacity reduction in women (Sharma, 1999).

Hence, it is necessary to provide farm women friendly Labor-saving, cost-effective and simple farming tools. Therefore, the goal of the current study is development of Womenfriendly weeding tools.

\section{Materials and Methods}

The experiment was carried out in 20 farmer's field of Tiruvallur district during the year 2017-18. The experiment comprised of 20 farm women belonging to age group of 25- 50 year who were working regularly in the field. The experiment for hand weeding method was conducted with 12 women farmers. These women farmers belonged to the age group of 25-40 years. They were strong and had no physical ailment. The grouping of health status of women was done on the basis of
BMI. The BMI scores were interpreted as per the classification given by Garrow (1987). Each respondent was checked for their heart rate (beats/min) and blood pressure $(\mathrm{mmHg})$ before and after weeding with different type of weeders. The heart rate (beats/min) and blood pressure $(\mathrm{mmHg})$ were checked during rest and work and recorded while working with traditional as well as different type of weeders viz., conoweeder and modified conoweeder.

The workload of the activity is classified according to the following classification of workload in different occupations proposed by Varghese et al., (1994).

\section{Results and Discussion}

\section{Physical characteristics}

Physical characteristics of basic human data are presented in Table 2. As shown in the table, the average age of selected farm women ranged from 25 to 40 years, with an average height of $142-150 \mathrm{~cm}$. Gross body weight in the range of $42-64 \mathrm{~kg}$. The average body mass index was calculated as 21.40 , which means they are within the normal range.

\section{Workload}

The occupational health and safety of farm women is the most neglected area in agriculture. The technological empowerment of farm women with occupational safety and better work output is the need of the day. According to Varghese et al., (1994), the workload during the activity period was classified based on average heart rate and average energy expenditure (Table 1). In the present study the heart rate (Using pulse oximeter) and Blood pressure (Digital blood pressure monitor) was recorded for the workers before and after weeding. The results revealed that the heart rate was increased 
while working with conoweeder (126 beats/min) compared to modified conoweeder (112 beats/min). In the same way the blood pressure also increased in hand weeding $(129 / 90 \mathrm{mmHg})$ and in conoweeder (132/89 $\mathrm{mmHg}$ ) compared to modified conoweeder (125/89 mmHg) (Table 3).

\section{Weeding efficiency}

The weeding efficiency was low in conoweeder and recorded more in manual weeding. Modified conoweeder recorded on par weeding efficiency with manual weeding. But in manual weeding time taken for covering one hectare in paddy was 192 hours. But in modified conoweeder the weeding can be done in 40 hours/ha. This method requires less time and labor cost than manual weeding. This buries the weeds and cuts the root system so weeds die before they can reestablish.

\section{Cost of operation}

The cost of operation of hand weeding was found maximum (Rs 9600/ha) followed by conoweeder (Rs 3200/ha) and modified conoweeder (Rs 2800/ha) (Table 3). Mechanical weeding involves less cost and has many advantages over the manual weeding process. Further it removes the weeds and loosens the soil surface so that water can easily be absorbed by the soil.

\section{Musculo-skeletal problems}

Musculo-skeletal problems and postures were assessed by asking respondents where they felt pain in their body after weeding with manual weeding, conoweeder and modified conoweeder.

It was revealed that performing stiff postures with traditional means causes severe pain in the shoulders, upper back, hands and fingers. Women considered the task heavy while doing hand weeding. In the contrary, using a better weeding device like modified conoweeder causes mild shoulder, arm and hand pain with mild discomfort / pain (Table 4).

Table.1 Classification of workload Varghese et al., (1994)

\begin{tabular}{|c|c|c|}
\hline Physical workload & Energy expenditure (KJ/Min) & Heart rate (beats/min) \\
\hline Very light & Upto 5 & Upto 90 \\
\hline Light & $5-7.5$ & $91-105$ \\
\hline Moderate & $7.6-10.0$ & $106-120$ \\
\hline Heavy & $10.0-12.5$ & $121-135$ \\
\hline Very heavy & $12.6-15.0$ & $136-150$ \\
\hline Extremely heavy & $<15$ & Above 150 \\
\hline
\end{tabular}

Table.2 (Physical characters of farm women)

\begin{tabular}{|l|c|}
\hline \multicolumn{1}{|c|}{ Physical characteristics } & Range \\
\hline Age (Years) & $25-40$ \\
\hline Height $(\mathbf{c m})$ & $142-150$ \\
\hline Gross weight $(\mathbf{K g})$ & $42-64$ \\
\hline Body mass index & 21.40 \\
\hline
\end{tabular}


Table.3 Heart rate (beats/min), blood pressure $(\mathrm{mmHg})$, weeding efficiency, time taken for weeding and weeding cost of different weeders in paddy

\begin{tabular}{|c|c|c|c|c|c|c|c|}
\hline \multirow[t]{2}{*}{ Technology Option } & \multicolumn{2}{|c|}{$\begin{array}{l}\text { Heart beat } \\
\text { (beats/min) }\end{array}$} & \multicolumn{2}{|c|}{$\begin{array}{l}\text { Blood Pressure } \\
\text { (mmHg) }\end{array}$} & \multirow{2}{*}{$\begin{array}{c}\text { Weeding } \\
\text { efficiency } \\
(\%)\end{array}$} & \multirow{2}{*}{$\begin{array}{c}\text { Time taken } \\
\text { for } \\
\text { weeding } \\
\text { hr/ha }\end{array}$} & \multirow{2}{*}{$\begin{array}{c}\text { Weeding } \\
\text { cost } \\
\text { Rs./ha }\end{array}$} \\
\hline & Before & After & Before & After & & & \\
\hline Manual Weeding & 90.6 & 106 & $110 / 70$ & $129 / 90$ & 89 & 192 & 9600 \\
\hline Conoweeder & 90.6 & 126 & $110 / 80$ & $132 / 89$ & 79 & 64 & 3200 \\
\hline Modified conoweeder & 90.6 & 112 & $110 / 80$ & $125 / 89$ & 88 & 49 & 2800 \\
\hline
\end{tabular}

Table.4 Average value of overall discomfort rating (ODR), Responses to muscular skeletal problems (MSP) and perceived exertion experienced by respondents

\begin{tabular}{|l|c|l|l|}
\hline \multicolumn{1}{|c|}{ Weeding method } & ODR & \multicolumn{1}{|c|}{ MSP } & \multicolumn{1}{|c|}{ RPE } \\
\hline $\begin{array}{l}\text { Traditional weeding } \\
\text { method }\end{array}$ & 7.8 & $\begin{array}{l}\text { Severe pain in shoulders, } \\
\text { upper back, hands and } \\
\text { fingers }\end{array}$ & Heavy \\
\hline Conoweeder & 6.5 & Moderate to light pain & Moderate \\
\hline Modified conoweeder & 5.6 & Moderate to light pain & Moderate \\
\hline
\end{tabular}

ODR=Mean value of overall discomfort rating; MSP=Musculo-skeletal problem; RPE=Rating of perceived exertion

\section{Implication of the study}

This study indicates that in order to ensure health, safety and well being and thereby improving the quality of work life and achieving higher productivity, it is essential that working implement must be designed ergonomically and should be women friendly. The weeding efficiency of the modified Conoweeder is on par with the hand weeding vis a vis eliminating the strenuous work load of hand weeding. The standing posture while using modified conoweeder was comfortable and exerted less pressure on the shoulders and hand. The time taken for weeding one hectare of paddy using Modified Conoweder is 40 hour which is 5 times lesser than the time required for manual hand weeding. The modified conoweeder is women friendly equipment in reducing the drudgery in farming operation to women farmers with high weeding efficiency.

\section{References}

Agarwal S. Gender involvement in farm mechanization issues for extension and research. NRC for Women in Agriculture, Bhubneshwar, India. 2007; II:51.

Garrow, J. (1987). Human Nutrition and Dietetics. Nutrition News 1991. National Institute of Nutrition, Hyderabad.

National Seminar on Women Farmer NSWF February Organized by Junagadh Agricultural University, Junagadh (Gujarat), Vigyan Parisar, Department of Science and Technology, Noida (UP) and National Council for Climate Change, Sustainable Development and Public Leadership, 
Ahmedabad (Gujarat), 2014.

Prakash, N., Rishikanta Singh Kh., Punitha P, S.S. Roy, M.A. Ansari and S.V. Ngachan (2014). Gender Mainstreaming in Small Farm Production System. Souvenir: 7th National Extension Education Congress in ICAR Research Complex for NEH Region, Umiam, Meghalaya during 8-11 November, 2014

Sharma V. Ergonomics assessment of weeding activity with conventional and modified tool. M.Sc. Thesis, Department of Family Resource
Management, College of Home Science, Maharana Pratap University of Agriculture \& Technology, Udaipur, Rajasthan, 1999.

Singh G. Equipment to ensure timeliness. The Hindu Survey of Indian Agriculture, M/S Kasturi and Sons Ltd., Chennai, 2002, 195-198.

Varghese, M. A., Saha, P. N., Atreya, N. (1994). A rapid appraisal of occupational workload from a modified scale of perceived exertion. Ergonomics, 37: 485-491.

\section{How to cite this article:}

Tamilselvi, C., R. Manimekalai, P. Yogameenakshi, V.A. Vijayashanthi and Sathish, M. 2020. Assessment of Drudgery Reduction of Different Weeders in Paddy for Farm Women. Int.J.Curr.Microbiol.App.Sci. 9(10): 598-602. doi: https://doi.org/10.20546/ijcmas.2020.910.071 